\title{
COLLECTIVE SECURITY IN AFRICA: THE TENSION BETWEEN THEORY AND PRACTICE ${ }^{1)}$
}

\author{
Evert Jordaan ${ }^{2)}$ \\ Faculty of Military Science \\ Stellenbosch University, South Africa
}

\section{Abstract}

The promotion of peace and security in Africa necessitates security cooperation between states and collective security remains a way to pursue it. This paper explores the changed meaning and application of the concept of collective security within the African Peace and Security Architecture (APSA) to deal with both interstate and intrastate security concerns within the African Union (AU). Since the AU has made clear commitments to collective security, the aim is to determine to what extent the AU subscribed to collective security and applied it in terms of coercion, which includes interventions. While dealing with genocide, war crimes and extended presidential terms remains problematic, the AU has taken an assertive stand with the use of coercion in cases of unconstitutional changes of government. The article highlights the tension between the theory and practice of collective security in Africa.

\section{Introduction}

The pursuance of security involves much uncertainty for states. Most countries find it difficult to promote their national security, by acting alone (Booth 1987: 303). States, therefore, often work together towards improving their security. According to Booth (1987: 261), "the absence of credible defensive alliances can leave the international system at the mercy of the aggressive". Modern states have in pursuance of security, not only relied on alliances and coalitions, but also on the rules-based system of collective security, which was a creation of Article 16 of the 
Covenant of the League of Nations and subsequently, the United Nations (UN), in an effort to establish and maintain international peace and security. Collective security is based on the principle that an attack on one state, is an attack on all states in the particular system; and that all states have to stop the aggressor. In Article 51 of the UN Charter, collective security is considered a legal right, together with self-defence. One of the main differences between alliances and collective security is that the former is established against a current and known threat, and the latter for future and unknown threats.

Since the establishment of the League of Nations and the UN, collective security has functioned as a parallel component of the changing international security landscape first with the balance-of-power system, followed by a post-Cold War unipolar system, with growing elements of a multipolar world. The system of collective security could not prevent the outbreak of the Second World War (1939-1945) and has been largely underutilised by the UN during the Cold War, mainly due to superpower rivalry in the UN Security Council. During the Cold War, the concept of peacekeeping was developed by the UN, which was not contained in the UN Charter (Boutros-Ghali 2009: xxii). The UN's successful collective response to Iraq's invasion of Kuwait (1990) created optimism that collective security could become the international norm in the post-Cold War era (Snyder 1999: 108-109). This optimism was, however, short-lived with the ineffective UN responses to crises in Somalia, Rwanda and the Balkans, as well as the inept nature of multinational UN peace operations. As a result, the permanent members of the UN Security Council in the West started to rely on the North Atlantic Treaty Organisation (NATO) to address security issues in Europe, while regions with less strategic importance, including sub-Saharan Africa, were largely avoided in terms of peace operations/deployments (Coleman 2011: 533). This effectively devolved much of the responsibility to deal with conflicts in Africa to regional and subregional organisations. The role of regional security institutions, therefore, became more prominent to deal with instability in Africa (Snyder 1999: 109).

Collective security had been designed mainly at the global level, but has become a prominent concept for regional and subregional security. Collective security was intended to deal mainly with interstate conflict, yet most armed conflicts since the Cold War have been intrastate in nature (Vogt 2009: 252-253). African countries have, therefore, adopted collective security principles to manage both interstate and 
intrastate conflict. Collective security features prominently in the African Peace and Security Architecture (APSA).

The aim of this article is to discuss the prominence of collective security in the AU's security architecture. This will be done by highlighting to what extent the AU subscribed to collective security, with specific reference to the collective use of coercion. The tension between the theory of collective security and practice is pointed out.

In the first part of the article, collective security as a concept is explained with reference to how it differs from alliances and other related concepts, and how the meaning and application of the concept has changed within the international system. Theoretical aspects on the concept collective security and the critique around the concept are discussed. The second part focuses on the prominence of collective security principles together with the principle of non-indifference within the APSA, as well as the AU's application of collective security with reference to the use of coercion. Reference is made to the crisis in Burundi, which highlights the tension within the AU between principles of non-interference and non-difference and thus also state-centric principles and collective security.

\section{Understanding collective security}

Between the end of the Napoleonic wars and the early 1900s, European countries formed part of a balance-of-power system (Papp 1997: 48-49). This is a system in which states pursue security within an anarchic context by joining alliances in order to prevent a single centre of power (a particular group of states) from dominating the international system and becoming expansionist (McLean 1996: 30-31). Within a balance-of-power system states can change alliances to promote equilibrium between centres of power (Papp 1997: 48-49). The balance-ofpower system, however, failed with the outbreak of the First World War and as a result of its horrific nature and aftermath, collective security was pursued through the League of Nations. One of the flaws of collective security is that one or more states may refuse to act when another member state is being attacked. This weakness contributed towards the outbreak of the Second World War, when several states invaded other countries, without any action being taken. This was the case during the invasion of Abyssinia (now Ethiopia) by Italy in October 1935, as well as the German invasion of Poland in September 1939. 
It is important to have conceptual clarity on the meaning of collective security for two reasons. Firstly, some literature on collective security uses the term alliances to describe 'collective security'. For example, Rappard (1946: 195) defined collective security as "the protection which so-called 'sovereign states' have sought to attain in their alliances against aggression". Secondly, the meaning of concepts such as collective security and alliances are often misused and distorted, especially by politicians (Booth 1987: 259). Booth (1987: 259), with particular reference to alliances, argued that such distortion of concepts often occurs where an impression of cohesion is created for very loose agreements for cooperation.

Alliances are a form of collective defence and involve formal agreements between states to work together in pursuance of their national security goals and focus on enhancing military power and coordinating deployments (Booth 1987: 258). Alliances can also be used to pursue common norms and interests, as well as to achieve a balance of power for the purpose of a stable international system (Chenoweth 2008: 64-65). Alliances usually involve a commitment between like-minded states against a known threat, which can include an opposing regional power. A collective defence organisation can be defined as a bilateral or multilateral military alliance between states for collective action against another state or set of states (Weitsman 2014: 26); for example the United States-Japanese Mutual Security Treaty (bilateral alliance), and the former multilateral alliance of the Warsaw Treaty Organisation/Warsaw Pact (Chenoweth 2008: 64-65). An alliance requires at least one state to use military force when necessary, and in general the level of military cooperation of each country, is an indication of its commitment to the alliance (Snyder 1999: 105). While alliances encompass long-term agreements, coalitions are of ad hoc and temporary nature to undertake a specific campaign or operation (Weitsman 2014: 26-27). Coalitions-of-the-willing may offer advantages in terms of composition and legitimacy, but often present practical problems in terms of command and control, and coordinating operations, due to lack of interoperability.

Collective security on the other hand, is a legally binding agreement between states (that are not necessarily like-minded) to not use force to resolve current or future disputes, and to act collectively against those states that break this rule (Snyder 1999: 107-109). It requires states to surrender some of their sovereignty to a supra-national body, 
which in this context would involve certain restrictions on autonomous military action (Chenoweth 2008: 65). Collective security, therefore, involves a rules-based system, in which collective and overwhelming action is taken against aggressor-states. According to Papp (1997: 153), collective security relies on "the major actors within the system accepting its legitimacy and responding together to punish those who did not". There are various perspectives on what collective security entails, which will receive attention.

There are several conditions for collective security to be successful (McLean 1996: 82-83). Firstly, states have to be content with the status quo including existing state boundaries and only use military force when defending other states or their own territory. Secondly, states must have consensus on what aggression means and in which instances member states have to defend one or more states. Thirdly, all member states and especially strong powers have to commit their armed forces and resources to stop aggression, or provide the necessary resources in time for another member state or states to do it. This must be done even for distant countries, where other states have little if any interests. Lastly, all member states must refrain from and avert any contravention of sanctions that may aid aggressor states.

Collective security exists when states conform to certain norms and rules to prevent major war and when necessary, stop acts of aggression (Kupchan and Kupchan 1995: 52-53). Competition between states contribute towards international stability (that is, balance of power), which should be harnessed within a regulated system instead of having "unregulated, self-help balancing predicated on the notion of each for his own" (Kupchan and Kupchan 1995: 52-53). The latter represents an anarchic setup where states only repel aggression when they are directly affected by it, or have vital interests at stake in a specific geographical area (Kupchan and Kupchan1995: 54-55). In a nutshell, their argument is that some form of collective security-institution to manage competition and disputes between states, is better than no institution. Collective security can thus also serve as an overarching system to control other forms of security cooperation, within a rulesbased system, based on international law.

Whereas much of the aspects of collective security involve a realist perspective of security, neoliberal institutionalists argue that collective security can facilitate the transformation of the competitive nature of state relations into a peaceful system of demilitarised interstate 
competition, based on the rule of law (Snyder 1999: 107-108). Collective security can, therefore, arguably be pursued by both realists and idealists. Neoliberal institutionalists furthermore argue that a collective security system can facilitate such a process by changing the interests and behaviour of states, as they become more aware of shared interests and security concerns (Snyder 1999: 107-108). It is also argued that as states subscribe to and apply the norms and rules of a collective security system, they may decide to continue this form of security cooperation and consequently build trust and enhance expectations of maintaining stability. By enhancing trust, it is argued that arms races and the security dilemma ${ }^{3)}$ can be avoided.

Collective security within the international system currently functions within the UN, with principles of collective security contained in the UN Charter (Snyder 1999: 108-109). The UN system of collective security is dependent on the cooperation of the five permanent members of the UN Security Council, namely the United States (US), Britain, France, Russia and China. During the Cold War, it was difficult to reach consensus on UN military interventions and, therefore, the UN military response to North Korea's invasion of South Korea in 1950, was an exception to the rule, since the Union of Soviet Socialist Republics (USSR) at the time boycotted the UN Security Council in an attempt to have the permanent Chinese seat on the Council allocated to the communist Chinese government and not Taiwan. Another unique case was UN approval for up-scaling the UN mission in the Congo (19601964) from a peacekeeping mission to an intervention mission in 1961 (United Nations 2001). The permanent members of the UN Security Council, therefore, control the UN's collective security system and decisions on sanctions and interventions. This means that individual states cannot rely on this system for support when facing a crisis in terms of national defence. Yet national defence has, since the Cold War, rarely been the biggest concern for most states, since transnational and intrastate threats have become more incessant and immediate threats.

The terrorist attacks on the US on 11 September 2001 (9/11), set in motion significant change in the interpretation and application of the concept of collective security, for pursuing more robust responses to international terrorism. In the 2004 'Report of the Secretary-General's High-level Panel on Threats, Challenges and Change', the use of military force for self-defence was considered justified, if a threat was 'im- 
minent' to a country's national security (United Nations 2004: 63, par 188). According to Boutros-Ghali (2009: $x x v$ ), this is a deviation from the UN Charter's Article 51, which makes provision for individual or collective self-defence only if an armed attack actually 'occurs' (BoutrosGhali 2009: xxv).

The above-mentioned report made several recommendations that became influential in terms of understanding and applying collective security within the UN context. Firstly, that the international community has a collective 'responsibility to protect' (R2P) civilians in any state suffering gross human rights violations, even if their own government does not take responsibility to protect them, or is itself guilty of atrocities against them (United Nations 2004: 65, par 201). Military intervention to protect civilians is, even without the permission of the 'host-nation' government, considered a possible, though last resort. The UN Security Council Resolution 1973 on 17 March 2011 regarding the protection of Libyan civilians, is an application of this principle. The subsequent intervention and regime change in Libya by NATO, is an example of its abuse.

The second recommendation of the High-level Panel, was that regional security structures have to fill the void in the UN's limited peace operations capacity and conduct peace operations within their regions, with UN approval and accountability to the UN (United Nations 2004: 69, par 220). Thirdly, that development is a foundation of collective security as part of an overarching effort to prevent conflict (United Nations 2004: 23), which is indicative of the human security paradigm of the UN, which also informs its emphasis on post-conflict reconstruction and development.

There are several points of critique regarding collective security. Firstly, that the definition of collective security is too restrictive, since it focuses on formal, legally-binding commitments by states to act, whenever an act of aggression occurs; and excludes informal institutional arrangements for security cooperation (Kupchan and Kupchan 1995: 53). Secondly, that the League of Nations and the UN in theory do not serve as ideal examples of collective security, since neither facilitated binding commitments to stop aggression (Kupchan and Kupchan 1995: 54). Moreover, the establishment of an 'inner council' to determine collective action in both these organisations (that is, Council of the League of Nations and the UN Security Council), is viewed as serving the interests of only a few great powers, rather than the international system. 
Thirdly, that within a large system of collective security with strong powers, many states may decide to 'free-ride' and not make significant contributions towards the collective security system. This could weaken the entire collective security system. Fourthly, that the possibility of having to use war in order to prevent it, makes the solution equally as destructive as the problem (Rappard 1946: 196 with reference to Walter Lippman). This could also make the implementation of collective security extremely expensive in terms of resources. Lastly, that collective security systems are generally unable to enforce their norms and, therefore, states have no guarantee that member states within the collective security system will actually come to their rescue, when being threatened or attacked.

Collective security is not a fool-proof solution to preventing war, since various efforts to do so, have failed (Kupchan and Kupchan 1995: 53). Optimism for collective security seems to increase shortly after devastating wars, but tends to wane when interstate tensions and threats rise, and states subsequently want immediate, decisive action through military coercion. Collective security has not worked in practice, which points to a disjuncture between theory and practice on this concept, as well as its weakness compared to the concept of alliances (Booth 1987: 302). Booth (1987: 303) argues that "collective security in its pure theory is a dream" and that neutralism and non-alignment are unlikely to become longstanding international norms. In the next sections, the extent to which collective security was embraced and applied by the AU, will receive attention.

\section{Collective security in Africa}

Since decolonisation various aspects have for long inhibited a unified approach to deal with crises and armed conflicts in Africa, which include post-colonial patronage, Cold War alignment and different views on security (Bach 2014: 182). For example, Pan-Africanists favoured the political and military unification of Africa and supported Nkrumah's proposal in 1958 for an African High Command and the inception of an African Legion (Franke 2008: 317). The nationalists, however, were hesitant to hand over their hard-earned sovereignty and, thus, opposed ideas of unification and collective intervention. This nationalist and internally-focussed view continued to strain closer security cooperation until the end of the Cold War (Franke 2008: 318). Instead of subscribing 
to the principle of collective security, many African states that became independent with decolonisation since the 1950s were, from a security perspective, relatively weak and opted for political neutralism and nonalignment in particular (Booth 1987: 302-303). This was an attempt to remain untouched by superpower rivalry.

The nationalist perspective has been the predominant perspective in Africa ever since the establishment of the Organisation for African Unity (OAU) in 1963 and it followed a non-interventionist approach to conflicts in Africa until 1993 (Domson-Lindsay 2015: 8-10). The OAU's principle of non-interference in domestic affairs inhibited action in cases where civilians suffered at the hands of their own governments. Examples of non-interference include the Nigerian Civil War (1967-1970) where millions starved; and the repressive rule of Idi Amin in Uganda (1971-1979) where thousands were killed (Ekwealor and Okeke-Uzodike 2016: 65). The OAU seemed to overlook serious human rights violations and to accommodate dictators. Widespread incidents of instability, such as foreign interventions, coups and mercenary activities in Africa, were stark reminders of the need for some form of collective security, especially since the OAU's security architecture had significant limitations.

The OAU, however, lacked the capacity for a collective security system. It did not have the necessary legal and institutional structure to conduct peace operations in accordance with the UN Charter (May and Massey 1998: 51). It also had major shortcomings in terms of logistic and financial capacity, which became evident in its first peacekeeping mission during the civil war in Chad between 1980 and 1982 (May and Massey 1998: 46-48). This was a precursor of difficulties that future African peace operations would face. ${ }^{4}$ Years later, the Economic Community for West African States (ECOWAS) decided to intervene on its own during the Liberian crisis (in August 1990), due to the OAU's failure in Chad and the UN Security Council's reluctance to intervene in the Liberian internal security situation. This was an indication that subregional organisations would in future play a more important role in terms of promoting security in Africa.

\subsection{The shift from non-interference to non- indifference}

The establishment of the OAU Mechanism for Conflict Prevention, 
Management and Resolution in 1993 could not address the OAU's capacity challenges to deal with conflict in Africa and given the UN's selective engagement at the time, the OAU conducted limited peace missions in the Great Lakes and the Comoros (Williams 2014: 68-69). It was up to subregional organisations to deal with internal conflicts and both ECOWAS and the Southern African Development Community (SADC) conducted several intervention operations since the early 1990s. However, military involvement in domestic conflicts also presented dilemmas. The international community and Africa's regional and subregional organisations learned hard lessons in the 1990s from the risks pertaining to casualties in peace operations in intense and complex internal conflicts such as Somalia, following the so-called Black Hawk Down incident; and the immorality of inaction (non-interference) during the Rwandan genocide (Vogt 2009: 254-255).

African states have subsequently moved from the principle of non-interference towards accepting the principle of non-indifference, which means that intervention in an intrastate conflict is justified when gross violations such as war crimes, genocide and crimes against humanity are occurring. This coincides with the broader international shift towards the principle of R2P (Engel and Porto 2014: 191). The OAU, which became the AU in 2002, together with African subregional organisations, decided to establish a security architecture and military capacity to deal with security emergencies in Africa, within the framework of the UN Charter. Mwanasali (2008: 41) describes this shift to the principle of non-indifference, as an interventionist phase in the continent's management of peace and security. Tension, however, still exists within Africa between the state-centred principles of non-interference and that of R2P.

Debates within the AU still take place on the principle of R2P; and have to be 'renegotiated' among member states on certain decisions, due to the tension with state-centred principles and thinking, which was predominant in the OAU (Engel and Porto 2014: 191). In Article 3 of the Constitutive Act of the AU (hereinafter referred to as the Constitutive Act), the AU aims to ensure the independence, sovereignty and territorial integrity of African states (AU Constitutive Act 2000: Article 3: 5). In Article 4 of the same Act, the AU upholds the following principles regarding the security of its member states: respect for existing national boundaries since independence; prohibition of the use of military force between states; and non-interference in the internal 
affairs of states (AU Constitutive Act 2000: Article 4: 6-7). Yet, the AU in principle rejects unconstitutional changes in governments and has the right to intervene in member states on request, or in cases of genocide, crimes against humanity and war crimes (AU Constitutive Act 2000: Article 4: 7). Bach (2014: 186) argues that the AU, by international standards, has the most prominent provisions for intervening in the domestic affairs of a member state. According to Mwanasali (2008: 52), the AU's principle of non-indifference implies that collective security decisions are binding on member states and take precedence over national political considerations or legislation. However, the opposing principles of non-interference in the internal affairs of states - versus the principle of non-indifference - can create difficulties in deciding on whether to intervene in a particular situation or not.

\subsection{The AU and collective security}

The AU considers peace, ${ }^{5)}$ stability and security as preconditions for development on the continent (AU Constitutive Act, 2000: 3). Furthermore, African countries consider their defence and security linked to each other and the continent as a whole (CADSP 2004: par 12(i), p 7). The AU views sustainable development as important for collective security, peace and stability (AU Non-aggression and Common Defence Pact 2005: 1). In this sense, development is viewed as a way to prevent insecurity, instability and war. The AU, therefore, follows a 'positive peace' perspective rather than a 'negative peace' perspective. The latter refers to the mere absence of war and personal violence, while 'positive peace' also includes social justice, the integration of human society, as well as development (Galtung 1969: 183).

The AU has rectified the legal framework for conducting peace operations in accordance with the UN Charter. The AU has accepted the provisions of the UN Charter and bestowed upon the UN Security Council "primary responsibility for the maintenance of international peace and security, as well as the provisions of the Charter on the role of regional arrangements ... in the maintenance of international peace and security" (AU Protocol 2002: par 5, p 1; and Article 17, par 1). The $\mathrm{AU}$, therefore, recognises the authority of the UN Security Council in overseeing collective security among UN member states. The AU, thus, provided the legal framework for connecting the AU and relevant subregional organisations in Africa to the international security architecture 
and collective security system of the UN (Vogt 2009: 256).

Collective security features prominently in the AU's principles regarding defence and security. In the Protocol Relating to the Establishment of the Peace and Security Council of the AU, the AU supports the promotion of collective security, together with the prevention of conflicts (AU Protocol 2002: 3). Article 2 of this Protocol makes provision for the establishment of the Peace and Security Council (PSC) of the AU, as a collective security and early-warning arrangement to prevent, manage and resolve conflicts (AU Protocol 2002: 4). The AU's commitment to collective security is reinforced in the AU Non-Aggression and Common Defence Pact (AU Defence Pact 2005: Article 2c: 7) which specifies that "any aggression or threat of aggression against any of the Member States shall be deemed to constitute a threat or aggression against all Member States of the Union" (AU Defence Pact 2005: Article 4a); and that states have to individually and collectively respond with all means available against aggression or threats thereof (AU Defence Pact 2005: Article 4b). The AU member states have, therefore, made a clear commitment to collective security.

The AU makes provision for collective responses to both interstate (or external threats) and intrastate/internal threats (CADSP 2004: par 13(a), p 8). African states have committed themselves towards collaboration and mutual assistance between member states to improve their security and intelligence capacities, as well as to combat transnational threats such as terrorism, organised crime and subversion (AU Defence Pact 2005: Article 5a, p 8). In Article 5 of the AU Defence Pact, African states undertook to prohibit the use of their territory as springboards for insurgency, terrorism or mercenary activities - into other states (AU Defence Pact 2005: Article 5). The AU Protocol also makes provision for a common African defence policy and African Standby Force (AU Protocol 2002: 4-5).

\subsection{AU decision-making on collective security measures}

Article 5 of the AU Protocol makes provision for the election of the 15member PSC, with equitable regional representation, by the Assembly of Heads of State and Government of the AU. The PSC is authorised to prevent and stop conflicts by means of (among others) peacemaking, sanctions and peace operations. The PSC can make recommenda- 
tions for interventions for approval by the Assembly (AU Protocol 2002: Article 7, par 1-e), and such approval requires a two-thirds majority in the Assembly (Constitutive Act 2000: Article 7, par 1). Decisions on deployments by the PSC have to be made by a quorum of at least ten members (AU Protocol 2002: Article 5, par 1; and Article 8, par 13), of which a two-thirds majority is required for taking action (AU Protocol 2002: Article 8, par 8). The AU, therefore, has an 'inner-council' that makes decisions on most deployments, except peace enforcement. Unlike the UN Security Council, no PSC member has a veto right to block interventions or sanctions (Engel and Porto 2011: 17).

The Chairperson of the AU Commission is responsible for executing the decisions of the PSC and for appointing special representatives and force commanders for missions (AU Protocol 2002: Articles 10 and 13). Article 13 of the AU Protocol (2002: 18-19) furthermore makes provision for the establishment of the African Standby Force (ASF), consisting of five subregional standby contingents to perform the following functions and missions, as directed by the PSC: observation and monitoring, preventative deployment, peace operations and interventions, peacebuilding, humanitarian assistance, post-conflict disarmament and demobilisation, as well as support in natural disasters (CADSP 2004: par 1(iii), p 18). The ASF has to cooperate with the UN and its agencies (AU Protocol 2002: Article 13, par 4). African countries are committed to "provide all possible assistance" to peace operations authorised by the PSC, as well as to the employment of the ASF (AU Defence Pact 2005: Article 10a, p 10). The ASF is, therefore, an AU military instrument for enforcing collective security in Africa.

Article 13 of the AU Protocol (2002: par 16, p 21), makes provision for close cooperation between the UN and the AU for the purpose of capacity-building for the ASF in terms of logistics, equipment, training, communications and funding. UN involvement in African peace operations, thus, made regional peace operations and the involvement of subregional powers more viable. According to Vogt (2009: 257) "African regional organisations are increasingly taking the lead in the initial stages of conflicts, hosting and leading political negotiations on the cessation of hostilities, and undertaking the first phases of military deployments, as occurred during the missions in Liberia in 2003 and Burundi in 2004". More recently, regional peace operations are considered precursors for UN or hybrid missions (Coleman 2011: 525).

The AU has made significant contributions to managing conflict 
in Africa. For example, the AU is currently involved in the so-called hybrid mission with the UN in Darfur (UNAMID). In addition, the AU is also conducting the African Union Mission in Somalia (AMISOM), as well as the Regional Cooperation Initiative for the elimination of the LRA (RCI-LRA) (African Union 2015b). A number of intervention and peace operations had also been conducted under the auspices of the AU and subregional organisations on the continent.

\subsection{Operationalising collective security in Africa}

Previously, it was highlighted that within the context of collective security, the AU has the authority to intervene in a member state in the following instances: to protect a member state against military aggression, on request of a member state, as well as in cases of genocide, war crimes and crimes against humanity. This section pays attention to the extent to which the AU applied collective security principles with specific reference to the use of coercion. How the AU deals with genocide, war crimes and crimes against humanity in terms of state actors, will be covered first.

\subsubsection{Genocide, war crimes and crimes against humanity}

The last genocide in Africa was the Rwandan genocide. Although Darfur is a controversial case following allegations of genocide, the International Commission of Inquiry on Darfur to the UN SecretaryGeneral concluded that the government of Sudan did not follow a policy of genocide, but that Sudanese government forces and militias committed crimes against humanity (United Nations 2005: 4). This Commission recommended that the matter be referred to the International Criminal Court (ICC), by the UN Security Council, which the latter did in 2005 (UN Security Council resolution 1593). Subsequently, the ICC issued warrants of arrest for President Omar El Bashir of Sudan (in May 2009 and July 2010), as well as Bashir's former Minister of Interior, Abdel Raheen Muhammed Hussein in March 2012 - for (among others) crimes against humanity and war crimes (ICC 2016). The AU, however, does not agree with the UN or the ICC decisions on this and expects these organisations to stop the prosecution of Bashir (African Union 2016b). The AU also expects its members to comply with the AU position - not to arrest Bashir. This is based on the principled decision 
that serving heads of state should enjoy immunity against prosecution, which led to the scrapping of the African Court of Justice and Human Rights' jurisdiction to prosecute serving heads of state, by means of an amendment of the AU protocol on this court in June 2014 (African Union 2014: Article 46A bis: 38-39). It also demonstrates the reluctance of the AU to intervene in Darfur, despite evidence of war crimes and crimes against humanity. Williams argues that this is an indication of the lack of consensus in the AU on how and when to consistently use its instruments of coercion (Williams 2010: 100). Considering the AU's limited military capacity to intervene, it is also easier for the AU to intervene in small countries with weak militaries such as the Comoros (Williams 2011: 156), than having to intervene in countries with significant military capacity such as Sudan, or without consent, which would strain unity within the AU. In late October 2016, both Burundi and South Africa gave notice to the UN Secretary-General that they were going to withdraw from the Rome Statute and consequently from the ICC (UN News Centre 2016). This is due to discontent and concerns that the ICC mainly prosecutes African leaders. This withdrawal raises fears that more African states could follow suit, which would be a major setback for the international system of criminal justice and the prevention of genocide, war crimes and crimes against humanity.

\subsubsection{Protection against military aggression}

Since interstate war is generally not a prominent phenomenon in Africa, the protection of $A U$ member states against acts of military aggression by other member states, is not a priority in Africa. Besides state interventions in civil wars (for example, Rwanda and Uganda in the Democratic Republic of Congo), the last interstate war between African countries, was between Ethiopia and Eritrea from 1998 to 2000 (Marshall 2016a). After the end of the Cold War, the OAU did not conduct any peace enforcement operations until 2002 and mostly conducted observer missions (Williams 2014: 68-73). Subregional organisations in Africa did, however, conduct several peace enforcement operations between 1990 and 2003. These included ECOMOG 1 (Economic Community Cease-Fire Monitoring Group) in Liberia from 1990 to 1999; ECOMOG 2 in Sierra Leone from 1997 to 2002; ECOMOG 3 in GuineaBissau from 1998 to 1999 which was both a peacebuilding and peace enforcement operation; Operation Sovereign Legitimacy was an opera- 
tion by SADC states (Angola, Zimbabwe and Namibia) in the Democratic Republic of the Congo (DRC) from August 1998-2002; and Operation Boleas was conducted by SADC states (South Africa and Botswana) in Lesotho from September 1998-1999. AMISOM in Somalia (since March 2007), with its robust mandate that makes provision for offensive operations, can also be considered a peace enforcement operation. The $\mathrm{AU}$, however, has only conducted one official peace enforcement operation, which was in the Comoros in 2008 to prevent secession (Operation Democracy in the Comoros). Peace enforcement operations since the establishment of the AU are, therefore, few in terms of frequency, which makes the requirement for collective security from an interstate-war perspective, low in demand.

African states and especially subregional powers have, due to limited capacity, become reluctant to conduct large-scale and drawnout peace operations or interventions, such as those conducted by the Economic Community of West African States (ECOWAS) in Liberia (1990-1997) and Sierra Leone from 1997 to 1999 (Coleman 2011: 525). Nigeria for example declined involvement in the ECOWAS mission in Côte d'Ivoire (ECOMICl) from 2002 to 2004 (Coleman 2011: 522). There was a realisation that African states do not have sufficient capacity to sustain such operations without additional support. With the establishment of the $\mathrm{AU}$, this realisation was already clear.

\subsubsection{Unconstitutional changes in government}

As mentioned in a previous section, the AU in principle rejects unconstitutional changes in government, within member states (AU Constitutive Act 2000: Article 4: 7). On 30 January 2007, the AU adopted the African Charter on Democracy, Elections and Governance (African Union 2007), which defined unconstitutional changes in government in terms of the following actions against a democratically elected government: coups; intervention by mercenaries; replacement by armed dissidents or rebels; the "refusal by an incumbent government to relinquish power to the winning party or candidate" after free and fair elections; as well as "amendment or revision of the constitution or legal instruments, which is an infringement on the principles of democratic change of government". The African Charter's definition, however, did not make provision for democratic uprisings, which later became problematic when the $A U$ had to decide on a course of action following democratic up- 
rising in Egypt against the regime of Hosni Mubarak, during the Arab Spring (Van Wyk 2014: 75).

In December 2009, the AU accepted the 'Ezulwini Framework for the Enhancement of the Implementation of Measures of the African Union in Situations of Unconstitutional Changes of Government in Africa', which strengthened measures for the implementation of an AU sanctions committee (AU Commission 2009: 1). Although the AU has been largely reluctant to intervene in the domestic affairs of member states, it has taken a strong position against unconstitutional changes in governments and has demonstrated steadiness in condemning coups in Africa (Williams 2011: 153-154). Yet the AU's view of unconstitutional changes to government was, at least initially, narrowly focussed on coups.

According to Vines (2013: 91-92), there were 12 coup d'etats in Africa between 2003 and 2012, of which the AU suspended most countries as depicted in Table 1. These included: the suspension of and sanctions against the Central African Republic (CAR) in 2003 following a coup by Bozize; AU sanctions against Togo in 2005 to apply pressure for elections following a coup; economic and other sanctions in the Comoros following separatist rebellion on the island of Anjouan in 2007, which was followed by the AU's first official military intervention in the following year; brief sanctions against Mauritania in 2009 following a coup; in December 2008 Guinea was suspended following a coup, which was followed by sanctions; in Madagascar, after the ousting of Ravalomana by Rajoelina, the AU imposed a travel ban against the Rajoelina administration; in 2010 the AU suspended Côte d'Ivoire following rigged elections under Gbagbo and also imposed sanctions; in 2012 the AU suspended Mali and endorsed ECOWAS sanctions following a military takeover; Guinea-Bissau was suspended in April 2012 after a coup; and in 2013 there were coups in the CAR and Egypt. Usually the AU lifts sanctions against member states after six months to two years, after elections have been held, or when governments start to comply with AU demands.

In most cases of coup d'etats, the AU imposed sanctions on the relevant countries, with the support of regional economic communities on the continent, the UN and in some cases even the European Union (EU) to enforce it (Vines 2013: 91-92). The AU, however, does not often take action against African governments that try to remain longer in power than what their countries' constitutions allow. The current situa- 
tion in Burundi seems to be another case in point.

\begin{tabular}{|c|c|c|c|}
\hline \multicolumn{4}{|c|}{ Table 1: Coup d'etats in the AU Since 2002} \\
\hline Country & Date/s & Occurrence & AU Response \\
\hline $\begin{array}{l}\text { Central Africar } \\
\text { Republic }\end{array}$ & $\begin{array}{l}2003 \\
2013\end{array}$ & $\begin{array}{l}\text { Coup }^{a} \\
\text { Coup }^{b}\end{array}$ & $\begin{array}{l}\text { Sanctions } \\
\text { Suspended }\end{array}$ \\
\hline Comoros & 2007 & Secession $^{\mathrm{C}}$ & $\begin{array}{l}\text { Sanctions; AU } \\
\text { Intervention (2008) }\end{array}$ \\
\hline Cote d'Ivoire & 2011 & $\begin{array}{c}\text { Civil War }^{\mathrm{d}} \\
\text { (post-election) }\end{array}$ & Sanctions $^{c}$ \\
\hline Egypt & 2013 & Coup $^{a}$ & Suspended \\
\hline Guinea & 2008 & Coup $^{a}$ & Suspended; Sanctions ${ }^{c}$ \\
\hline Guinea-Bissaı & $\begin{array}{l}2003 \\
2012\end{array}$ & $\begin{array}{l}\text { Coup }^{a} \\
\text { Coup }^{a}\end{array}$ & $\begin{array}{l}\text { No Suspension } \\
\text { Suspended }\end{array}$ \\
\hline Mali & 2012 & Coup $^{b}$ & $\begin{array}{l}\text { Suspended }{ }^{\mathrm{e}} \text {, Sanctions; } \\
\text { Asset Freezes \& Travel } \\
\text { Bans }^{\mathrm{c}}\end{array}$ \\
\hline Madagascar & 2009 & Coup $^{C}$ & $\begin{array}{l}\text { Suspended }{ }^{\mathrm{e}} \text {, Travel ban } \\
\text { on leaders of Rajoelina } \\
\text { administration }^{\mathrm{c}}\end{array}$ \\
\hline Mauritania & $\begin{array}{l}2005 \\
2008\end{array}$ & $\begin{array}{l}\text { Coup }^{a} \\
\text { Coup }^{a}\end{array}$ & $\begin{array}{l}\text { Suspended }^{\mathrm{e}} \\
\text { Suspended, Sanctions }^{\mathrm{C}}\end{array}$ \\
\hline Niger & 2010 & Coup $^{a}$ & Suspended $^{\mathrm{e}}$ \\
\hline Togo & 2005 & Coup $^{a}$ & Suspended $^{\mathrm{e}}$, Sanctions ${ }^{\mathrm{C}}$ \\
\hline \multicolumn{4}{|c|}{$\begin{array}{cl}\text { Sources: } & \\
\text { a. } & \text { Marshall and Ramsey Marshal (2016). } \\
\text { b. } & \text { Marshall (2016a). } \\
\text { c. } & \text { Vines (2013). } \\
\text { d. } & \text { Marshall, (2016b). } \\
\text { e. } & \text { Souaré (2014). } \\
\end{array}$} \\
\hline
\end{tabular}

\subsubsection{The case of Burundi}

The AU's decisions on the ongoing crisis in Burundi have become an important case for the $\mathrm{AU}$ in terms of testing the importance of the principle of non-indifference (in order to protect civilians) versus noninterference in a state's domestic affairs and the principle of state sovereignty. This crisis has involved large-scale violence, killings, human rights abuses and displacement of people, following the announcement in April 2015 that President Pierre Nkurunziza was nominated for a third term in office, which was before Burundi's Constitutional Court's ruling in favour of another term (Bedzigui and Alusala 2016: 2-3). Serious alle- 
gations of political pressure on the Constitutional Court judges' ruling have been made. The security situation was aggravated by an attempted coup in May 2015 and subsequent government repression.

On 17 October 2015, the PSC decided to impose targeted sanctions and travel bans against Burundians who contributed to the continuation of violence (African Union 2015a: par 12). On 17 December 2015, the PSC in light of the deteriorating security situation in Burundi, decided to authorise the deployment of 5000 peacekeepers to form the African Prevention and Protection Mission in Burundi (MAPROBU), to monitor the security situation, protect civilian populations under threat, create conditions for dialogue, to facilitate an agreement between parties as well as the disarmament of militias and the protection of political leaders (African Union 2015c: 3). The Burundian government has, however, refused to allow the deployment of the AU peacekeeping force and would consider their deployment an invasion (Bedzigui and Alusala 2016: 5-7). At the PSC Summit (at the level of Heads of State and Government) on 29 January 2016, in contrast to its earlier position, member states did not support a peacekeeping deployment in Burundi, nor the implementation of any sanctions (African Union 2016a: par 11). The Burundian government has furthermore refused to allow 228 UN police officers to deploy in the country as mandated by UN Security Council Resolution 2303 of 29 July 2016 (African Union 2016c: par 7). The AU has, thus, decided to defer the deployment of the MAPROBU peacekeeping force. The AU has deployed an undersized group of human rights observers and military experts to Burundi, which is largely unable to conduct its work in the absence of a memorandum of understanding between the $\mathrm{AU}$ and the Burundi government (Bedzigui and Alusala 2016: 4). The current indecision in the AU regarding Burundi is an indication that there is still no clear consensus on the primacy of nonindifference versus non-interference, or how and when the coercive instruments of the AU should be used for continental security. Moreover, this case also highlights the tension between a rules-based and supranational approach (of the AU Commission) versus the statecentric views of $A U$ member states.

\subsubsection{Challenges for collective security in Africa}

The AU faces various overall challenges that put pressure on the continental security system and which constrain the operationalisation 
of collective security. According to Williams, African states do not uphold the ideals of the $\mathrm{AU}$ in terms of self-restraint to prevent the perpetuation of armed conflict, nor follow a principled approach to deal with it (Williams 2010: 101-102). Instead of the latter, African states often choose sides around an insurgency between a government and rebels. African states lack cooperation on political and security issues, which complicates continental consensus-building on issues such as how to reform the UN Security Council. Interpersonal relations between many African heads of state are strained and one cannot assume that African statesmen will consider their neighbouring countries' military inventories as common regional security assets and not as potential threats. Furthermore, several AU missions involve troop contributing countries with a direct interest in stabilising the particular country and supporting its regime (Coleman 2011: 530). For example, Uganda is in effect running the AU mission in Somalia (AMISOM) in an attempt to curb alShabaab. Many of these challenges are aspects that AU member states have undertook to avoid.

\section{Conclusion}

The aim of this paper was to discuss the prominence of collective security within the APSA, by highlighting to what extent these organisations subscribed to collective security and applied it in terms of coercive measures. The AU member states have clearly committed themselves to the principles of collective security within the context of the APSA.

The concept of collective security underwent significant changes in terms of scope since the inception of the League of Nations. Initially it focussed mainly on keeping international peace by preventing interstate war between states through a legally binding agreement that if one state in a system is attacked, the others will come to its aid. More recently, collective security is applied on a regional level in Africa for both interstate and intrastate threats. Following the Rwandan genocide and 9/11, a more pre-emptive and interventionist approach to collective security was followed internationally, which focussed on responding to imminent threats, as well as protecting civilians and preventing gross violations of human rights, such as genocide. This was later referred to as R2P. This required the OAU and later the AU to make a shift from the narrow principle of non-interference towards accommodating nonindifference. Yet, the AU did not discard state-centred principles of re- 
spect for national boundaries and non-interference in domestic affairs. This makes for a difficult balancing act, which still produces major tension within the AU to act consistently in dealing with crises, and determining courses of action with its extensive powers to intervene. This portrays the tension that exists between the theory and practice of collective security through so-called 'inner councils', which subordinate the functioning of collective security to the narrow interests of a few states, as opposed to a strict rules-based collective security system.

The AU accepted collective security in accordance with the UN Charter, which provides a legal framework for connecting the AU and subregions in Africa to the international collective security system overseen by the UN. The AU has only conducted one intervention operation since its inception, which was to stop a secession in the Comoros in 2008. The AU and its subregions have, however, been involved in many peace enforcement and peacekeeping operations in intrastate conflicts. Some of these operations could arguably be viewed as collective security applied to intrastate conflicts, for example AMISOM. Although the AU often tussles with renegotiating the application of nonindifference in cases like Darfur and currently in Burundi, the AU has taken an assertive stand on unconstitutional changes to governments and on coup d'etats in particular. The most common AU response in such cases, is to suspend member states, which is often accompanied by sanctions, as a form of coercion.

The success of collective security depends on a number of strong powers that are willing and able to enforce the norms and rules of collective security. Collective security is a workable, yet imperfect and unreliable system for vulnerable countries and populations. Although national defence has, since the Cold War, rarely been the biggest concern for most states, the weaknesses and possible failure of collective security measures can put significant pressure on core states such as South Africa and Nigeria in keeping subregions in Africa stable. Ultimately the integrity and success of both alliances and collective security are tested when states have to act to protect the peace, and there are usually no guarantees that one or more states will actually come to the aid of a victim state or population, or that they will do so with commitment and the desired effect. 


\section{Endnotes}

1. This paper was delivered at the South Africa Armour Symposium on 20 October 2016, in Bloemfontein. The views expressed in this article are those of the author and not the Department of Defence.

2. Lecturer, Military Strategy Department, Faculty of Military Science, Stellenbosch University.

3. The security dilemma occurs when the one state's efforts to enhance its own security, makes another country insecure (Hough 2013: 3).

4. The Common African Defence and Security Policy, 2004, par 19, p 12, describes funding and logistics as fundamental problems and constrains on both OAU and AU peace operations.

5. Johan Galtung argued that there are two types of peace. Firstly, 'negative peace' which is the absence of both violence and war, as well as personal violence. Secondly, 'positive peace' which goes beyond the mere absence of war, and which characterises the absence of structural violence (social injustice), and an integration of human society. Social justice would then involve an egalitarian distribution of power and resources, as well as 'vertical development'. There is, therefore, a close connection between positive peace and development (cf Galtung 1964 and 1969).

\section{Bibliography}

African Union (2000), Constitutive Act of the African Union, adopted by the 36th Ordinary Session of The Assembly of Heads of State and Government of the Organisation of African Unity, Lome, Togo, 11 July 2000.

African Union (2002), Protocol Relating to the Establishment of the Peace and Security Council of the African Union, adopted by the First Ordinary Session of the Assembly of the African Union, Durban, South Africa, 9 July 2002.

African Union (2004), Solemn Declaration on a Common African Defence and Security Policy (CADSP), Second Extraordinary Session, Sirte, Great Libyan Arab Jamahiriya, on 28 February 2004.

African Union (2005), Non-Aggression and Common Defence Pact, adopted by the Fourth Ordinary Session of the Assembly, held in Abuja, Nigeria, 31 January 2005.

African Union (2007), African Charter on Democracy, Elections and Governance, adopted on 30 January 2007.

African Union (2014), Protocol on Amendments to the Protocol on the Statute of the African Court of Justice and Human Rights, Addis Ababa, Ethiopia, 27 June 27.

African Union (2015a), Communique: Peace and Security Council 551 $1^{\text {st }}$ Meeting, 
Addis Ababa, Ethiopia, 17 October.

African Union (2015b), Peace Operations conducted by the African Union and Partners, 20 November. (Available at: http://www.peaceau.org/en/page/72peace-ops, last accessed 30 July 2016).

African Union (2015c), Peace and Security Council $656^{\text {th }}$ Meeting, Addis Ababa, Ethiopia, 17 December.

African Union (2016a), Communique: Peace and Security Council $571^{\text {st }}$ Meeting at the Level of Heads of State and Government, Addis Ababa, Ethiopia, 29 January.

African Union (2016b), Assembly of the Union, Twenty-Sixth Ordinary Session: Decisions, Declarations and Conclusions, Assembly/AU/Dec.590(XXVI), Addis Ababa, Ethiopia, 30-31 January.

African Union (2016c), Communique: Peace and Security Council $631^{\text {st }}$ Meeting, Addis Ababa, Ethiopia, 6 October.

African Union Commission (2009), Ezulwini Framework for the Enhancement of the Implementation of Measures of the African Union in Situations of Unconstitutional Changes of Government in Africa, 17-19 December 2009, pp 1-10.

Bach, D C (2014), "Regionalism in Africa: Concepts and Context", in Hentz, J J (ed), Routledge Handbook of African Security. London: Routledge, pp 181189.

Bedzigui, Y and N Alusala (2016), "The AU and the ICGLR in Burundi", Central Africa Report, Issue 9, Institute for Security Studies, September, pp 1-15.

Booth, K (1987), "Alliances", in Baylis, J et al (eds), Contemporary Strategy: Theories and Concepts (2nd ed). New York: Holmes \& Meyer.

Boutros-Ghali, B (2009), "Foreword", in Adebajo, A (ed), From Global Apartheid to Global Village: Africa and the United Nations. Scottsville: University of KwaZulu-Natal Press.

Chenoweth, E (2008), "A Contested Threat: The Politics of Security Collaboration for Combating Terrorism", in Wilson, I and J J F Forest (eds), The Handbook of Defence Politics: International and Comparative Perspectives. London: Routledge, pp 64-75.

Coleman, K (2011), "Innovations in 'African Solutions to African Problems': The Evolving Practice of Regional Peacekeeping in Sub-Saharan Africa", Journal of Modern African Studies, Vol 49, No 4, pp 517-545.

Domson-Lindsay, A K (2015), "Peace and Security in Africa: Past, Present and Future", Journal of African Union Studies, Vol 4, No 2 and 3, pp 5-33.

Engel, U and J G Porto (2011), "The African Union's New Peace and Security Architecture: Towards an Evolving Security Regime?", in Söderbaum, F, and $\mathrm{R}$ Tavares (eds), Regional Organizations in African Security. London: Routledge, pp 14-28. 
Engel, U and J G Porto (2014), "The African Union and African Security", in Hentz, J J (ed), Routledge Handbook of African Security. London: Routledge, pp 190-197.

Ekwealor, C T and U Okeke-Uzodike (2016), "The African Union Interventions in African Conflicts: Unity and Leadership Conundrum on Libya", Journal of African Union Studies, Vol 5, No 1, pp 63-82.

Franke, B (2008), "Africa's Evolving Security Architecture and the Concept of Multilayered Security Communities", Cooperation and Conflict: Journal of the Nordic International Studies Association, Vol 43, No 3, pp 313-340.

Galtung, J (1964), "An Editorial", Journal of Peace Research, Vol 1, No 1, pp 1-4. Galtung, J (1969), "Violence, Peace and Peace Research", Journal of Peace Research, Vol 6, No 3, pp 167-191.

Hough, P (2013), Understanding Global Security ( $3^{\text {rd }}$ ed). New York: Routledge. International Criminal Court (ICC), Situation and Cases: Pre-trial Stage. (Available at: https://www.icc-cpi.int/Pages/pre-trial.aspx, accessed 27 September 2016.) Kupchan, C A and C A Kupchan (1995), "The Promise of Collective Security", International Security, Vol 20, No 1, pp 52-61.

Marshall M G and D Ramsey Marshal (2016), Coup d'etat Events, 1946-2015: Codebook, Center for Systemic Peace. (Available at: http://www.systemicpeace.org/inscrdata.html, last accessed 8 September 2016.)

Marshall, M G (2016a), Major Episodes of Political Violence (MEPV) and Conflict Regions, 1946-2015, Center for Systemic Peace, 25 May. (Available at: http://www.systemicpeace.org/inscrdata.html, last accessed 8 September 2016.)

Marshall, M G (2016b), Major Episodes of Political Violence and Conflict Regions, 1946-2015, Center for Systemic Peace, 25 May. (Available at: http://www. systemicpeace.org/warlist/warlist.htm, last accessed 8 September 2016.)

May, R and S Massey (1998), "The OAU Intervention in Chad: Mission Impossible or Mission Evaded?", International Peacekeeping, Vol 5, No 1, pp 46-65.

McLean, I (1996), Concise Dictionary of Politics. Oxford: Oxford University Press.

Mwanasali, M (2008), "From Non-interference to Non-indifference: The Emerging Doctrine of Conflict Prevention in Africa", in Akokpari, A et al (eds), The African Union and its Institutions. Auckland Park: Fanele.

Papp, D S (1997), Contemporary International Relations: Frameworks for Understanding $\left(5^{\text {th }}\right.$ ed). Boston: Allyn and Bacon.

Rappard, W E (1946), "Collective Security", The Journal of Modern History, Vol 18, No 3, September, pp 195-201.

Snyder, C (1999), "Regional Security Structures", in Snyder, C (ed), Contemporary Security and Strategy. New York: Routledge.

Souaré, I K (2014), "The African Union as a Norm Entrepreneur on Military Coups 
d'etat in Africa (1952-2012): An Empirical Assessment", Journal of Modern Africa Studies, Vol 51, No 1, pp 69-94.

United Nations (2001), Republic of the Congo - ONUC Background. (Available at: http://www.un.org/Depts/DPKO/Missions/onucB.htm, last accessed 29 July 2016.)

United Nations (2004), A More Secure World: Our Shared Responsibility, Report of the Secretary-General's High-level Panel on Threats, Challenges and Change.

United Nations (2005), Report of the International Commission of Inquiry on Darfur to the United Nations Secretary-General, pursuant to Security Council Resolution 1564 of 18 September 2004, Geneva, 25 January 2005. (Available at: http://www.un.org/news/dh/sudan/com_inq_darfur.pdf, last accessed 24 September 2016.)

United Nations News Centre (2016), "Withdrawal from International Criminal Court could send 'wrong message' - UN chief", 28 October. (Available at: http:// www.un.org/apps/news/story.asp?NewsID=55427\#.WCo569V97IU, last accessed 15 November 2016.)

United Nations Regional Information Centre (UNRIC) (2008), United Nations Charter.

Van Wyk, J (2014), "Electoral Authoritarianism and Democratisation in Africa: The Role of the African Union", Politeia, Vol 33, No 2, pp 63-81.

Vines, A (2013), "A Decade of African Peace and Security Architecture", International Affairs, Vol 89, No 1, pp 89-109.

Vogt, M (2009), "The UN and Africa's Regional Organisations", in Adebajo, A (ed), From Global Apartheid to Global Village: Africa and the United Nations. Scottsville: University of KwaZulu-Natal Press.

Weitsman, P A (2014), Waging War: Alliances, Coalitions, and Institutions of Interstate Violence. Stanford: Stanford University Press.

Williams, P D (2010), "Explaining and Understanding Security Cooperation in Africa", African Security Review, Vol 19, No 2, pp 97-105.

Williams, P D (2011), War \& Conflict in Africa. Cambridge: Polity Press.

Williams, P D (2014), "Peacekeeping in Africa after the Cold War: Trends and Challenges", in Hentz, J J (ed), Routledge Handbook of African Security. London: Routledge, pp 66-82. 